This is an accepted manuscript of an article published by Taylor \& Francis in Japanese Studies on 23/01/2007 available online at http://www.tandfonline.com/10.1080/10371390500226290

A Genealogy of 'Japanese' Self-images

EIJI OGUMA (David Askew, trans.)

Melbourne: Trans Pacific Press, 2002

xxxvi + 435 pp., translator's commentary, introduction to English language edition, map, chronology, notes, references, index

ISBN 1-878-4303-7 AUS\$59.95 pb

\title{
Morris, Narrelle
}

The original Japanese edition of Eiji Oguma's work, entitled Tan'itsu minzoku shinwa no kigen"Nihonjin" no jigazô no keifu (The Origins of the Myth of a Homogenous Nation - The Genealogy of "Japanese" Self-Images), was published by Shinyôsha in 1995 and won Japan's Suntory Culture award in 1996. As revealed in David Askew's translator's note, while this new volume is ostensibly a translation of the Japanese edition, the degree to which Askew collaborated with Oguma has almost made this new English version a revised edition.

Oguma's interest lies in Japanese discourses on the origin of the nation. He systematically examines the historical and sociological 'genealogy' of Japan's self-identity, as expressed by modern Japanese writers in numerous fields, including history, anthropology, ethnology, linguistics and philosophy. Oguma divides his book into three parts, entitled 'The Thought of an "Open Country", "The Thought of "Empire" and "The Thought of an "Island Nation"'. The three parts are a roughly chronological analysis of the process by which various theories of Japan's origins began and altered over time. The first part examines the 'birth' of such theories from the middle of the Meiji period (1868-1911) until the start of the Japanese empire in the early twentieth century; the second part, writings from the period of justifying imperial rule in Asia; and the third part, writings of the World War II and post-war periods.

Oguma is particularly drawn to ongoing perceptions of Japan as homogenous. As he reports, many Japanese writers, particularly those in the subset of literature known as Nihonjinron (theories of the Japanese), have expressed arguments that the Japanese nation 'has consisted, and today, still consists, of only the Japanese nation, which shares a single, pure origin, and a common culture and lineage' (p. xxx). In recent discourse, this has been called the 'myth' of the homogenous nation, which was established as a part of kokutai (national polity) ideology in the Meiji period.

Oguma agrees that that homogeneity of Japan is a 'myth' but contends the tacit acceptance of many historians that the Meiji period was the starting point for the 'myth'. As Oguma describes, the early 
years of modern Japanese nationalism in the 1880s saw widespread acceptance of the idea that Japan was a 'mixture' of indigenous and incoming peoples. By the turn of the twentieth century, Oguma concludes there was 'no anthropological support for the homogenous nation theory' in Japan (p. 29). Japan's expansion into empire with the incorporation of Taiwan in 1895, Korea in 1910 and parts of China in the 1930s and early 1940s saw a 'sudden explosion' in the rhetoric of the 'mixed nation theory', which remained in mainstream public discourse until about mid-World War II (pp. 81, 285).

Oguma thus establishes that ideas regarding Japan's homogeneous origins are, in fact, considerably more modern, having been argued by such wartime theorists as the eugenicists Kiyono Kenji (18851955) and Hasabe Kotondo (1882-1969), who based their conceptions on the 'scientific' study of physical measurements, and ethicist Watsuji Tetsurô (1889-1960), who based his on a theory of climate. Their basic ideas achieved rampant popularity in the post-war period, when theorists had to formulate a new, empire-less vision of Japan. As Oguma concludes, the self-image of Japan as a homogenous and, consequently, a 'peaceful and tranquil' nation proved to be 'very attractive' to the shattered Japanese population (p. 299). It was an image that dovetailed well with Japan's post-war social, economic and political condition. For example, Japan's economic prosperity dating from the 1960s was attributed to Japan's homogeneity by both Japanese and non-Japanese proponents of Nihonjinron who attempted to articulate the 'secret' to Japan's success. Oguma ends with a call not just to overcome the 'myth' of homogeneity in Japan but for all people to 'liberate ourselves from all myths' (p. 349).

The book presents a very comprehensive analysis of various theories of the origins of Japan, with particular focus on the history of the 'myth' of homogeneity. It is an ambitious study, covering a century of intellectual thought in many disciplines. The tying together of these narrative threads is the book's major contribution to discourse and yet is also its weakness. Oguma's roughly chronologically structuring of the book has led to a somewhat disjointed volume, where noted writers, their personal histories, their writings, critiques by contemporaries and the author's commentary appear across multiple chapters. On page 69, which is part of chapter five, for example, Oguma comments that relevant discussion is also found in chapters two, eleven and fourteen. Similarly, on pages 72-73 the reader is guided to chapters one, twelve, fourteen and seventeen. Given that Oguma roughly divided his theorists into those who followed the 'mixed nation' theory and those who did not, at any given time, it may have been better to structure the book to follow these two interpretations. 
In terms of the translation, Askew often seems to rigidly stick to Oguma's original text, which means that the style in English is occasionally awkward. For example, in a section discussing pioneering anthropologist Tsuboi Shôgorô, one sentence reads: 'It is therefore not true that some personality trait meant that he [Tsuboi] could not exchange views with scholars in England' (p. 13). However, no such suggestion had earlier been made. The same section also reveals some unusual analysis by Oguma. Tsuboi, he declared, was not a 'conservative, anti-Western individual'. However, Oguma's evidence for this statement is a quotation from Torii Ryûzô, a student of Tsuboi, to the fact that Tsuboi brought more books back to Japan following his sojourn overseas than any other student. This seems to suggest that to qualify as anti-Western, one had to eschew Western learning, and the buying of Western books, entirely.

These are, however, niggling complaints to what is a comprehensive study of self-identity in Japan. With Oguma's statement that he does 'not believe that the Japanese nation is an entity that actually exists' (p. xxxvi) and his call to end our reliance on 'myths', one cannot escape the implication that Oguma thinks 'nations', too, should be relegated to the past. This should extend the fruits of Oguma's analysis to studies of other 'nations'. 